\title{
Decadal change in the boreal summer intraseasonal oscillation
}

\author{
Tsuyoshi Yamaura $^{1} \cdot$ Yoshiyuki Kajikawa $^{1}$
}

Received: 9 November 2015 / Accepted: 17 June 2016 / Published online: 25 June 2016

(C) The Author(s) 2016. This article is published with open access at Springerlink.com

\begin{abstract}
A decadal change in activity of the boreal summer intraseasonal oscillation (BSISO) was identified at a broad scale. The change was more prominent during August-October in the boreal summer. The BSISO activity during 1999-2008 (P2) was significantly greater than that during 1984-1998 (P1). Compared to P1, convection in the BSISO was enhanced and the phase speed of northward-propagating convection was reduced in $\mathrm{P} 2$. Under background conditions, warm sea surface temperature (SST) anomalies in P2 were apparent over the tropical Indian Ocean and the western tropical Pacific. The former supplied favorable conditions for the active convection of the BSISO, whereas the latter led to a strengthened Walker circulation through enhanced convection. This induced descending anomalies over the tropical Indian Ocean. Thermal convection tends to be suppressed by descending anomalies, whereas once an active BSISO signal enters the Indian Ocean, convection is enhanced through convective instability by positive SST anomalies. After P2, the BSISO activity was weakened during 2009-2014 (P3). Compared to P2, convective activity in the BSISO tended to be inactive over the southern tropical Indian Ocean in P3. The phase speed of the northward-propagating convection was accelerated. Under background conditions during P3, warmer SST anomalies over the maritime continent enhance convection, which strengthened the local Hadley circulation between the western tropical Pacific and the southern tropical Indian Ocean. Hence, the convection in
\end{abstract}

Tsuyoshi Yamaura

tyamaura@ riken.jp

1 RIKEN Advanced Institute for Computational Science, Computational Climate Science Research Team, Kobe 650-0047, Hyogo, Japan the BSISO over the southern tropical Indian Ocean was suppressed. The decadal change in BSISO activity correlates with the variability in seasonal mean SST over the tropical Asian monsoon region, which suggests that it is possible to predict the decadal change.

\section{Introduction}

Asian summer monsoon variability is directly linked to water resources and natural disasters due to the rainfall amount and heavy rainfall events. Hence, many studies have examined its physical mechanism as well as the climatological dynamics (e.g., Charney and Shukla 1981; Murakami and Matsumoto 1994; Wang and LinHo 2002). Interannual variability is one of the most important features of the Asian summer monsoon. Because the El Niño/Southern Oscillation (ENSO) has a large impact on the interannual variability of the Asian summer monsoon, ENSO-monsoon relationships have been considered in many studies (e.g., Kawamura 1998; Wang et al. 2001; Yamaura and Tomita 2014). Variability at a timescale longer than interannual variability has become a major issue for studies of the global climate due to the increase in the available observational datasets and improvements in the global circulation model. Thus, the climate change events around 1976 in the North Pacific (e.g., Nitta and Yamada 1989; Trenberth and Hurrell 1994) and around 1990 (e.g., Watanabe and Nitta 1999) were detected and investigated. The decadal variability of the Asian summer monsoon has also been studied in recent years, e.g., in the East Asian summer monsoon (Tomita et al. 2007; Zhou et al. 2009) and the western north Pacific monsoon (Kajikawa and Wang 2012; Tomita et al. 2013).

The Asian summer monsoon largely consists of the convective activity associated with the intraseasonal 
oscillation (ISO). The boreal summer intraseasonal oscillation (BSISO), which is represented as the Madden Julian Oscillation (MJO; Madden and Julian 1994) in summer, shows an active-break cycle of convective activity with northward propagation for a 30-60 day period in the tropical Asian monsoon region (e.g., Ramamurthy 1969; Murakami 1972; Hartmann and Michelsen 1989; Wang and Xie 1997; Jiang et al. 2004). Because this active-break cycle directly corresponds to the rainfall over the Asian monsoon region, many researchers have discussed the physical mechanism of the active-break cycle (Wang and Xie 1997; Stephens et al. 2004; Wang et al. 2005).

The relationship between BSISO activity and interannual variability in the Asian summer monsoon has been examined in terms of its predictability. Sperber et al. (2000) indicated that the dominant mode in the BSISO activity and interannual variability of the Asian summer monsoon have similar spatial features. The BSISO activity is correlated with the interannual variability of the South Asian monsoon strength (Goswami and AjayaMohan 2001). These results suggest that BSISO activity influences the interannual variability of the Asian summer monsoon. The contribution of internal variability primarily originating from the BSISO activity, to external forcing, such as the component related to the ENSO, is important for predictability of the interannual variability of the Asian summer monsoon. AjayaMohan and Goswami (2003) demonstrated that internal variability largely contributes to the interannual variability of the Asian summer monsoon. On the other hand, limitations in predictability of BSISO activity have been investigated by many researchers (Goswami and Xavier 2003; Webster and Hoyos 2004). The predictability of the BSISO activity may be linked to improvements in interannual variability in the Asian summer monsoon.

In contrast to interannual variability, the long-term variability of broad-scale BSISO activity has rarely been considered due to data limitations. A better understanding of the decadal variability controlled by external forcing could improve the predictability of BSISO activity. Recently, Kajikawa et al. (2009) reported that BSISO activity over the South China Sea demonstrates decadal change before and after 1994. Sabeerali et al. (2014) reported that tropical Indian Ocean warming in the 2000s can enhance South Asian monsoon activity and reduce the phase speed of the northward propagation of convection. They used subseasonal variability of precipitation in the South Asian monsoon region. However, BSISO activity appeared at a broad scale across the Asian summer monsoon region from the tropical Indian Ocean to the western Pacific. It remains to be determined if the spatiotemporal structure of the BSISO activity in the entire Asian monsoon region demonstrates a decadal change. Kikuchi et al. (2012) considered the bimodal ISO index to be useful for displaying the phase and amplitude of the BSISO and MJO activity, respectively. This index could be used to investigate the long-term change in BSISO activity on a broad scale. Because BSISO activity has seasonal dependency (Kemball-Cook and Wang 2001), whether the decadal variability in the BSISO activity shows seasonal dependency is an interesting question. Therefore, this study focused on the following three issues: (1) Does BSISO activity show decadal change on a broad scale? (2) If decadal change exists, is there any seasonality? (3) What are the differences in spatiotemporal structure of the BSISO decadal change? In this study, we focused on the BSISO with a periodicity of 25-90 days because this ISO has a large effect on the Asian summer monsoon than the biweekly mode has (Yasunari 1981; Hartmann and Michelsen 1989).

The rest of this paper is organized as follows. Section 2 describes the data and methodology used in this work. We demonstrate the existence of long-term variability in BSISO activity in Sect. 3. The characteristics and mechanism of the long-term variability in BSISO activity and its possible source are discussed in Sects. 4 and 5. Finally, a summary of this work and further discussions are given in Sect. 6.

\section{Data and methodology}

This study used the following three datasets: (1) daily mean outgoing longwave radiation (OLR) data compiled by the National Oceanic and Atmospheric Administration (NOAA) (Liebmann and Smith 1996); (2) 6-hourly and monthly mean data for atmospheric parameters of the European Centre of Medium-Range Weather Forecasts (ECMWF) Interim Re-Analysis (ERA-Interim; Dee et al. 2011); and (3) daily and monthly mean optimum interpolated sea surface temperature (SST) data compiled by NOAA (Reynolds and Smith 1994). We used an interpolated OLR, which represents the period from 1979 to 2013, and a non-interpolated OLR, which represents the period from 2002 to 2015. The non-interpolated OLR includes undefined values where the OLR was not observed. We interpolated the undefined value according to the method of Liebmann and Smith (1996) for applying the bandpass filter. The root mean square error between non-interpolated and interpolated OLR data during the overwrapped period of 2002-2013 was $3.52 \mathrm{~W} \mathrm{~m}^{-2}$. The mean OLR was $216.97 \mathrm{~W} \mathrm{~m}^{-2}$ in the original interpolated OLR data and $216.90 \mathrm{~W} \mathrm{~m}^{-2}$ in the processed non-interpolated OLR data. The error was about $1.6 \%$ of the mean OLR. We concluded that the processed non-interpolated OLR data were useful for the extension of the OLR data period. We used the interpolated OLR data from 1979 to 2013 and the processed non-interpolated OLR data during 2014-2015. 
The Lanczos bandpass filter (Duchon 1979) with cut-off periods of 25 and 90 days and 141 weights was applied to the daily data to extract the ISO signal. To obtain the amplitude and phase of BSISO, we used the daily BSISO index, which is one of bimodal ISO indexes (Kikuchi et al. 2012). ${ }^{1}$ This index is based on the extended empirical orthogonal function (EEOF) analysis results of bandpass-filtered OLR data during the boreal summer with -10 and -5 day lags. The amplitude and phase of the BSISO are described using a combination of the first two principal components for EEOF. Therefore, the amplitude of the BSISO index corresponds to the strength of BSISO activity. Normalized amplitude of more than 1 was regarded as a significant BSISO event. Using the OLR data, two types of daily BSISO index were prepared: a historical daily BSISO index, which was computed from the interpolated OLR data during 1979-2013 and a real-time daily BSISO index, which was evaluated from the non-interpolated OLR data during 2002-2015. The average amplitudes of the two daily indexes during 2002-2013 were both $1.01 \mathrm{~W} \mathrm{~m}^{-2}$, and the root mean square error of the real-time BSISO index was $0.011 \mathrm{~W} \mathrm{~m}^{-2}$. Both the amplitude and phase errors were less than $1.5 \%$. We merged the historical daily BSISO index from 1979 to 2013 and the real-time daily BSISO index from 2014 to 2015.

To investigate the meridional and vertical structure of the BSISO activity, we used a composite analysis. A composite was constructed, with the first day of phase 1 of the BSISO index displayed at day 0. Composite data were subtracted from the long-term mean and applied to the above bandpass filter before the composite analysis.

\section{Decadal change in BSISO activity}

The climatological BSISO is active from May to October (Kikuchi et al. 2012). Figure 1 shows the year-to-year variation in BSISO activity averaged from May to October (MJJASO). The red line denotes the composition of the first three harmonics, with a Fourier decomposition of the normalized BSISO index, which indicates the decadal component. The decadal component of the BSISO index was large and positive during 1999-2008, but was relatively small in 1984-1998. It is interesting to note that the BSISO activity weakened in 2009-2014. Here, we define the BSISO weak period (1984-1998) as P1, the enhanced period (1999-2008) as P2, and the period after P2 (20092014) as P3. The differences in the averaged BSISO activity between $\mathrm{P} 1$ and $\mathrm{P} 2$ and between $\mathrm{P} 2$ and $\mathrm{P} 3$ were significant at the $1 \%$ level (Table 1). This implies that a

\footnotetext{
$\overline{1}$ http://iprc.soest.hawaii.edu/users/kazuyosh/Bimodal_ISO.html.
}

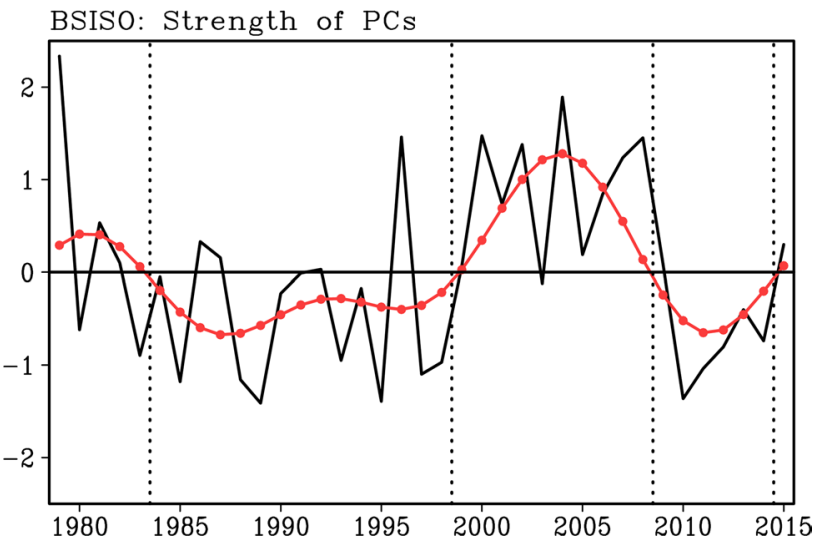

Fig. 1 Time series of the normalized BSISO index averaged from May to October (black line), with the decadal component of the normalized BSISO index (red line with closed circle). The ordinate indicates the strength of BSISO activity (no unit), and the abscissa is the year

climatological shift in BSISO activity occurred around 1999 and 2009. Hence, the BSISO activity had significant decadal variability. In addition, the decadal variability of BSISO activity by using the Real-time Multivariate MJO index (Wheeler and Hendon 2004) was not clear. This suggests that the decadal change of the BSISO has meridional asymmetricity.

Because the climatological BSISO has a different spatial structure in early and late summer (Kemball-Cook and Wang 2001), we examined the epochal difference in BSISO activity on a monthly mean basis (Fig. 2). The decadal change in the BSISO activity showed seasonal dependence. The amplitude of the BSISO index in P2 (P1 and P3) was larger (smaller) than the all-year average in all of the boreal summer months. The amplitude of the BSISO index during P2 (red line) exceeded 1 from May to October. During P1 (green line), it exceeded 1 from June to July, but was less than 1 in other months. By contrast, the BSISO activity in P3 (blue line) exceeded 1 only in August. Table 1 summarizes differences in the monthly and seasonally averaged BSISO activity between P1-P2 and between P2-P3. The BSISO activity between P1 and P2 was significantly different in May, August-October, and on average during August-October (ASO) and MJJASO. The decadal change of BSISO activity was insignificant on average during May-July (MJJ). The decadal change in the BSISO activity from P1 to P2 displayed seasonal dependency. The BSISO activity between P2 and P3 was significantly different in all of the boreal summer months, except June and as a seasonal average (MJJ, ASO, and MJJASO). To investigate the cause of the decadal change in BSISO activity, we therefore focused on ASO for the changes from P1 to P2, and on July-October (JASO) for the change from P2 to P3 in the following sections. 
Table 1 The probability value of the monthly (from May to October), MJJ, ASO, and MJJASO averaged BSISO index following a Welch's $t$-test during P1 (1984-1998) and P2 (1999-2008), and in P2 and P3 (2009-2014)

\begin{tabular}{llllllllll}
\hline & May & Jun & Jul & Aug & Sep & Oct & MJJ & ASO & MJJASO \\
\hline P2-P1 & $\mathbf{0 . 0 2}$ & 0.66 & 0.06 & $\mathbf{0 . 0 0}$ & $\mathbf{0 . 0 1}$ & $\mathbf{0 . 0 2}$ & 0.07 & $\mathbf{0 . 0 0}$ & $\mathbf{0 . 0 0}$ \\
P3-P2 & $\mathbf{0 . 0 1}$ & 0.07 & $\mathbf{0 . 0 1}$ & $\mathbf{0 . 0 5}$ & $\mathbf{0 . 0 3}$ & $\mathbf{0 . 0 4}$ & $\mathbf{0 . 0 0}$ & $\mathbf{0 . 0 0}$ & $\mathbf{0 . 0 0}$ \\
\hline
\end{tabular}

The bold figures indicate significance at the $5 \%$ level

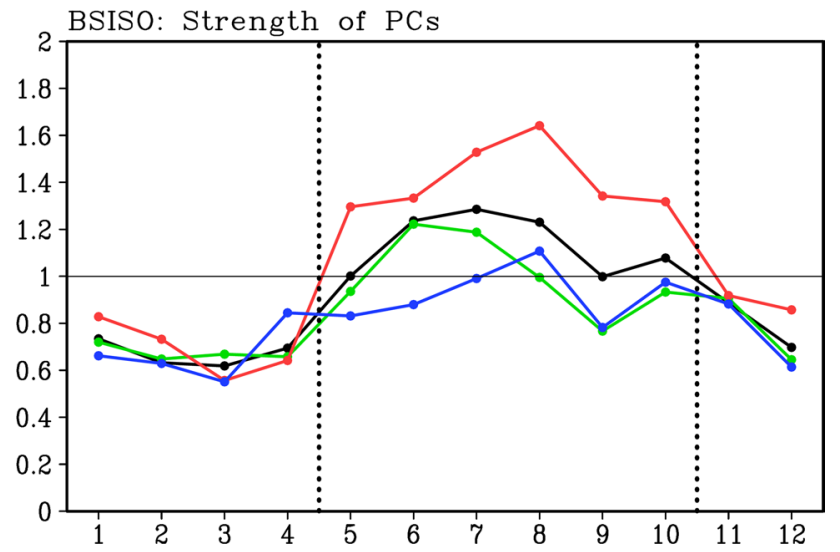

Fig. 2 The temporally averaged BSISO index in each month. The black line displays the annual average (1979-2015). The green, red, and blue lines indicate the period in 1984-1998 (P1), the period in 1999-2008 (P2), and the period in 2009-2014 (P3), respectively. The ordinate expresses the strength of the BSISO activity (no unit), and the abscissa is the month

\section{The intensified BSISO activity from 1984 to 1998 and from 1999 to 2008}

First, we investigated the differences in the spatial pattern of decadal change of BSISO activity. Figure 3 shows the ratio of bandpass-filtered OLR amplitude to the total daily variance for ASO during $\mathrm{P} 1$ and $\mathrm{P} 2$. This corresponds to the strength of BSISO activity. A common feature in P1 and P2 was the large amplitude of OLR, which accounted for about $40 \%$ of the total daily variance in the tropical Indian Ocean and around the Philippines. This spatial pattern is consistent with previous studies (e.g., Kemball-Cook and Wang 2001; Kajikawa and Yasunari 2005). Enhanced BSISO activity in P2 was apparent over the equatorial Indian Ocean and the South China Sea (Fig. 3c), which is consistent with Sabeerali et al. (2014). In contrast, the ratio was relatively small in the Philippine Sea.

The typical convective activity related to the BSISO gradually moved northeastward from the tropical Indian Ocean to the western Pacific (e.g., Jiang et al. 2004; Drbohlav and Wang 2005; Kikuchi et al. 2012). The northward propagation of convective activity tended to be emphasized in late summer (Kemball-Cook and Wang 2001). To highlight the decadal change in the temporal structure of convective activity, we produced a Hovmöller

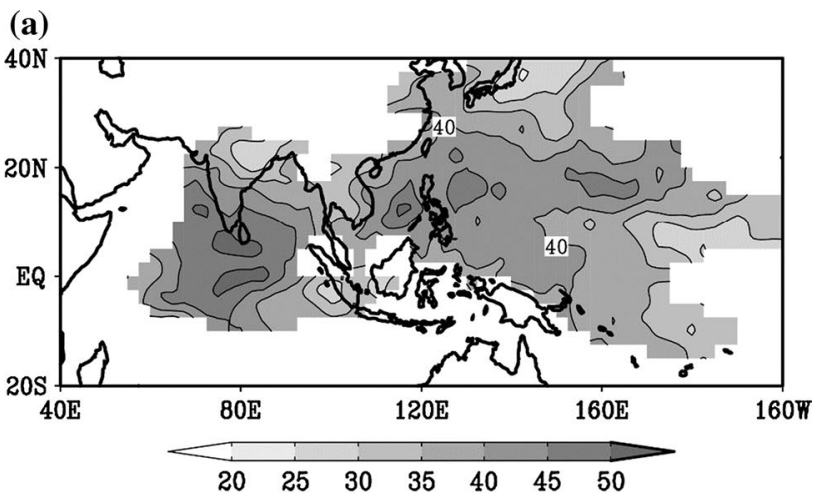

(b)

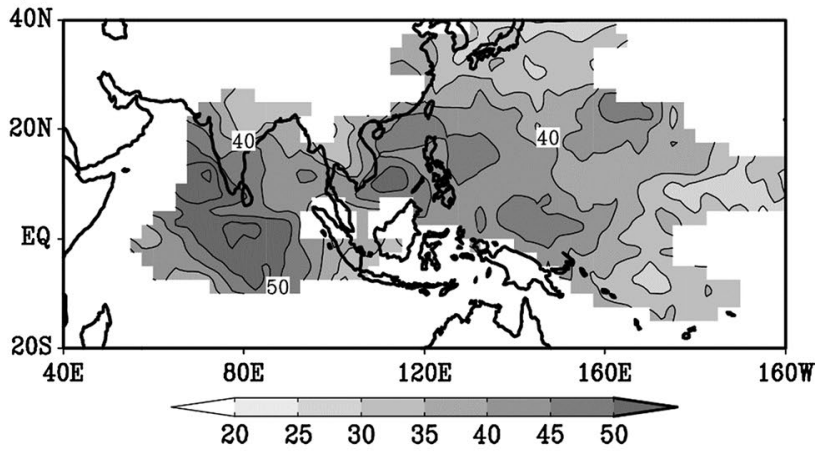

(c)

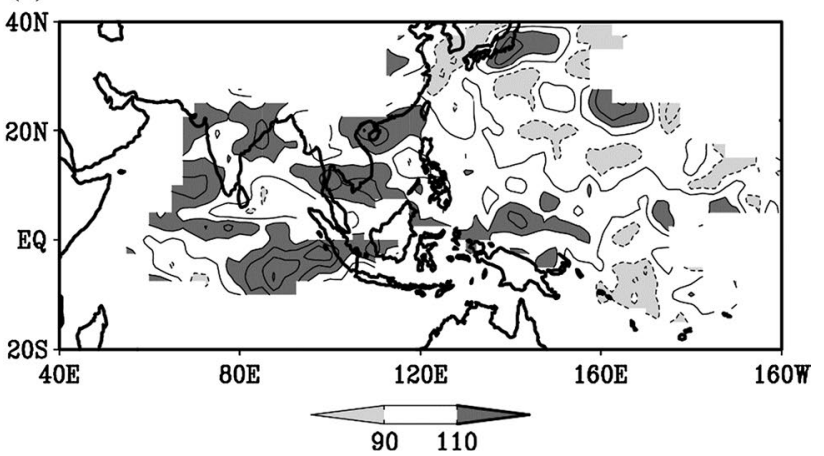

Fig. 3 The ratio of bandpass-filtered OLR amplitude to the total variance (\%) during ASO in a P1 and b P2. c The ratio of P2 to P1 (\%). Only the areas with a standard deviation of daily OLR more than $30 \mathrm{~W} \mathrm{~m}^{-2}$ are shown. The scales of shading are shown on the bottom of each panel

diagram of composite anomalies of OLR and SST during P1 and P2, respectively (Fig. 4). A common feature in P1 and $\mathrm{P} 2$ was the enhanced convection that started over the 

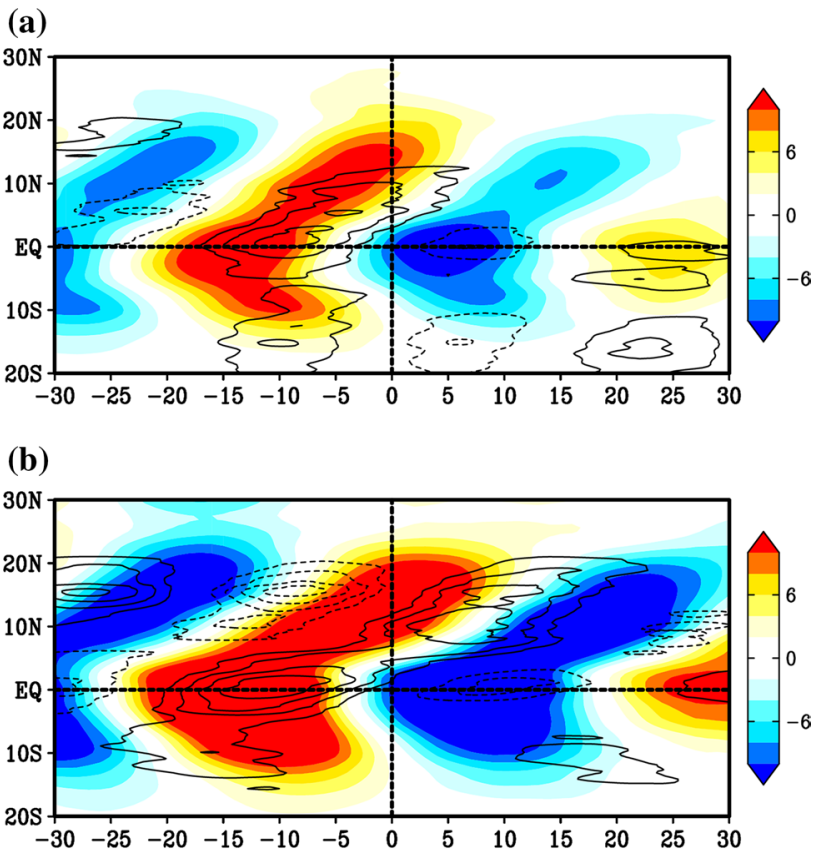

(c)

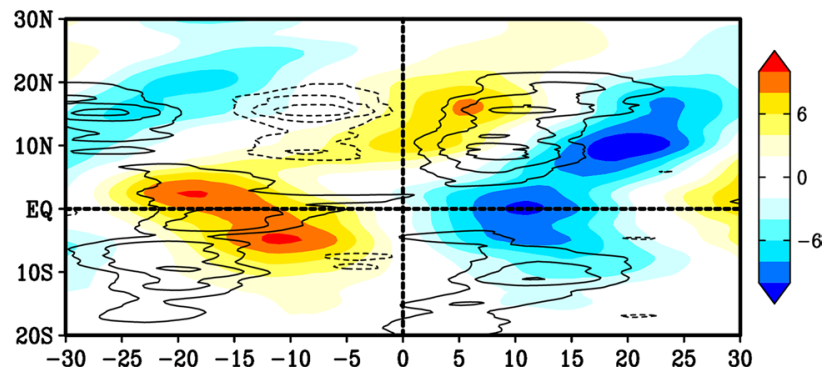

Fig. 4 Hovmöller diagram of composite OLR (shading; $\mathrm{W} \mathrm{m}^{-2}$ ) and SST (contour; K) averaged between $70^{\circ}$ and $90^{\circ} \mathrm{E}$ in a P1, b P2, and c the differences (P2-P1) during ASO. The contour interval is $0.04 \mathrm{~K}$. Negative values are indicated by dashed contours. The scales of shading are shown at the right of each panel. The ordinate is latitude, and the abscissa is lead-lag days

equator from day 0 and propagated the convection anomalies northward and southward. At the same time, negative SST anomalies appeared near the equator. Before day 0 , suppressed convection anomalies and positive SST anomalies were apparent in the tropical Indian Ocean. Positive SST anomalies reinforced by suppressed convection enable production of the next active convection (Wang et al. 2005). Air-sea interactions can enhance the convection related to BSISO activity. Compared with P1 (Fig. 4a), the amplitude of the OLR and SST anomalies was large in P2 (Fig. 4b). The phase speed of the northward propagation of convection decreased from P1 to P2 (Table 2). The temporal structure of eastward propagation of the BSISO was also investigated, but its phase speed difference between P1 and P2 was not statistically significant (Table 2).
Table 2 The day displaying the minimum composite OLR at the equator and $10^{\circ} \mathrm{N}\left(70^{\circ} \mathrm{E}\right.$ and $\left.130^{\circ} \mathrm{E}\right)$ in $\mathrm{P} 1$ during $\mathrm{ASO}, \mathrm{P} 2$ during ASO, P2 during JASO, and P3 during JASO

\begin{tabular}{lllll}
\hline & P1 (ASO) & P2 (ASO) & P2 (JASO) & P3 (JASO) \\
\hline $\begin{array}{l}\text { Northward } \\
\text { Minimum OLR }\end{array}$ & 5 & 7 & 7 & 7 \\
$\quad \begin{array}{l}\text { at 0N } \\
\text { Minimum OLR at } \\
\quad 10 \mathrm{~N}\end{array}$ & 14 & 18 & 17 & 13 \\
$\quad$ Phase Speed & 1.11 & 0.91 & 1.00 & 1.67 \\
$\begin{array}{l}\text { Eastward } \\
\text { Minimum OLR at }\end{array}$ & 6 & 11 & 10 & 9 \\
$\quad \begin{array}{l}\text { Minimum OLR at } \\
\quad \text { 130E }\end{array}$ & 22 & 29 & 24 & 23 \\
Phase Speed & 0.63 & 0.56 & 0.71 & 0.71 \\
\hline
\end{tabular}

Day 0 is the start of a BSISO event. The phase speed was estimated between the equator and $10^{\circ} \mathrm{N}\left(70^{\circ} \mathrm{E}\right.$ and $\left.130^{\circ} \mathrm{E}\right)$

Figure 5 shows the average composite vertical structure of moisture and atmospheric circulation when a convection center appeared between the equator and $10^{\circ} \mathrm{N}(\mathrm{P} 1$ : days 5-14, P2: days 7-18; Table 2). The composite anomalies of ascending motion, moisture convergence in the lower troposphere, and vertically consistent positive vorticity appeared near the region with active convection between the equator and $10^{\circ} \mathrm{N}$ as common features in $\mathrm{P} 1$ and $\mathrm{P} 2$ (Fig. 5a-d). These characteristics were identified as active convection related to BSISO activity, which was consistent with previous studies (Jiang et al. 2004; Sabeerali et al. 2014). Compared with P1, these composite anomalies were further emphasized in P2 (Fig. 5e, f). This implies the convection anomalies were strengthened in $\mathrm{P} 2$, which is linked to the enhanced BSISO activity.

We then investigated the possible mechanism of the decadal change in BSISO activity from P1 to P2. The longterm variability can be connected to the changes in ocean conditions because of its large heat capacity. To diagnose the oceanic and atmospheric conditions associated with the decadal change of BSISO activity, we demonstrated the epochal differences in OLR, SST, vertical wind shear composed of $200 \mathrm{hPa}$ zonal winds subtracted from $850 \mathrm{hPa}$, moisture at $1000 \mathrm{hPa}$, and the vertically $(1000-300 \mathrm{hPa})$ integrated moisture flux during ASO between P1 and P2 (Fig. 6). Negative OLR anomalies were elongated along $20^{\circ} \mathrm{N}$ in the region with the Asian summer monsoon and northwest-southeast direction from the western equatorial Pacific to the South Pacific convergence zone (Fig. 6a). Positive OLR anomalies were apparent at both the east and west sides of the negative OLR anomalies. With the convective anomalies, easterly moisture flux anomalies in the lower troposphere were apparent to the east of the negative 

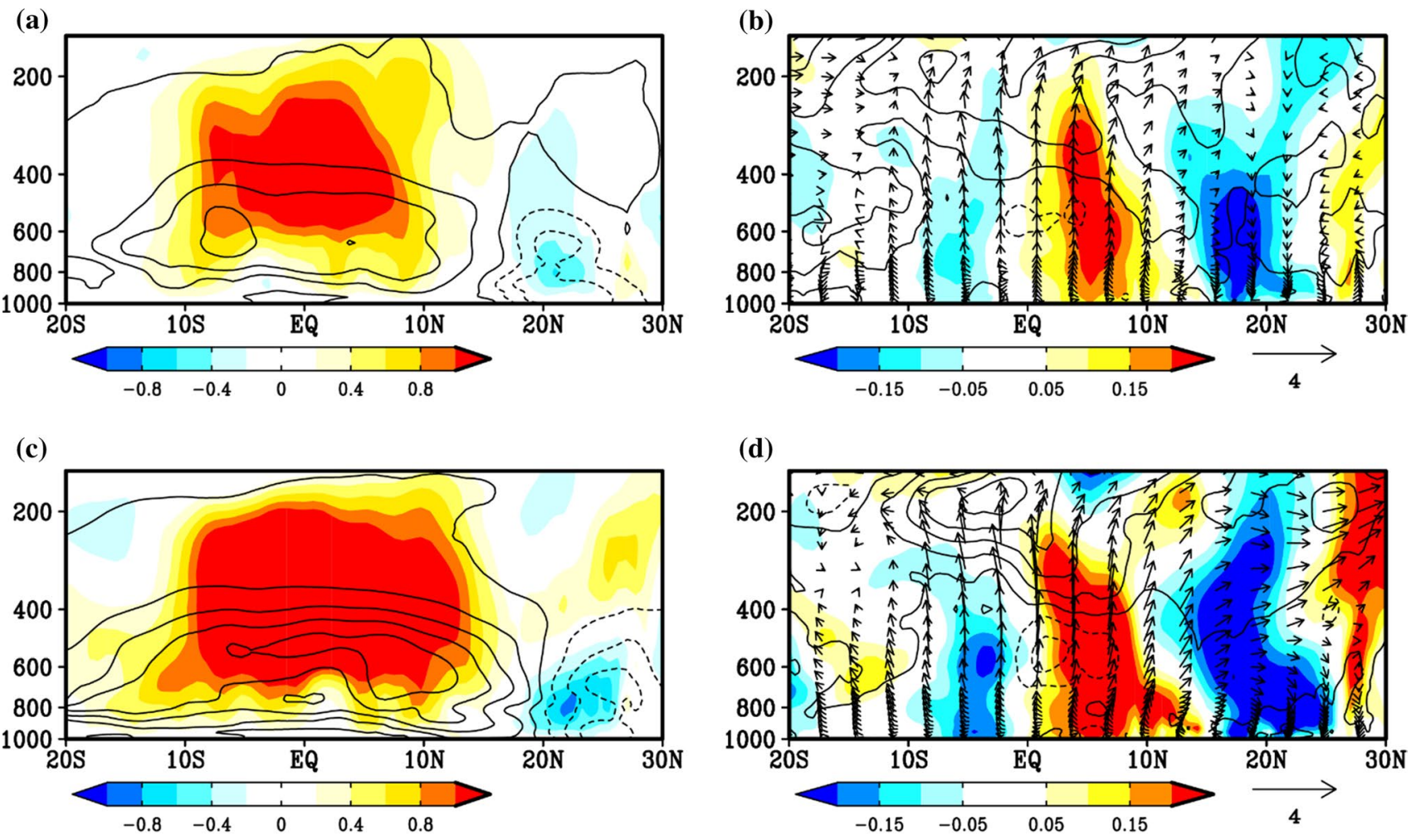

(e)

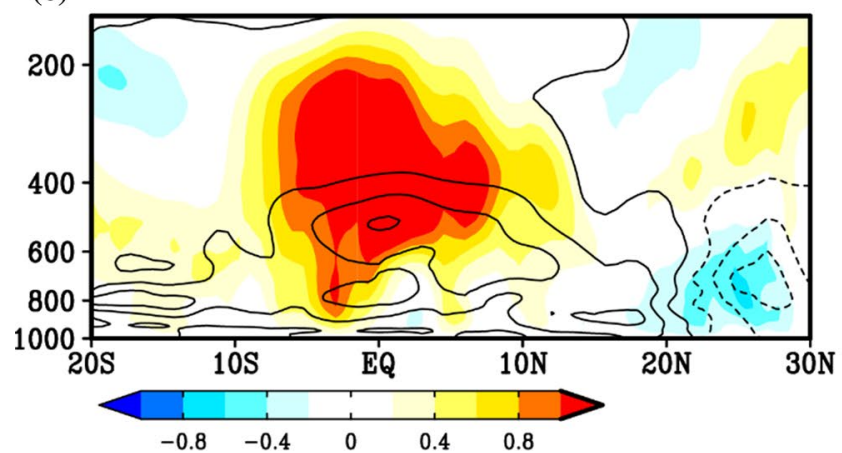

(f)

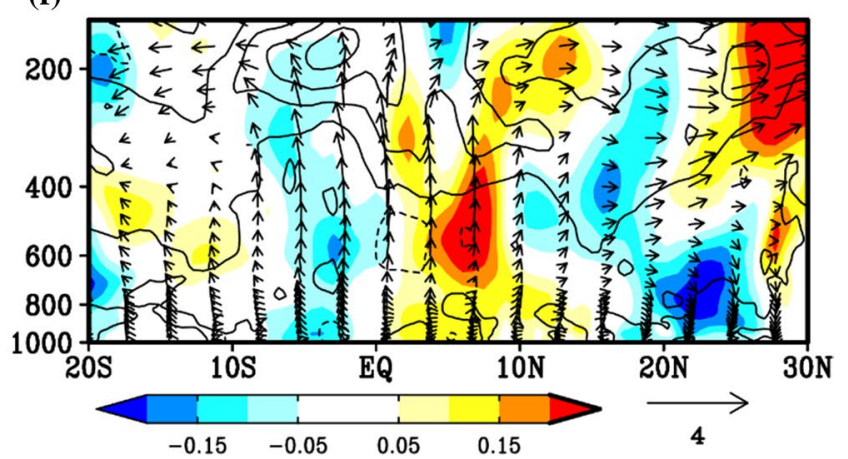

Fig. 5 Latitude-height cross section averaged between $70^{\circ}$ and $90^{\circ} \mathrm{E}$ in $\mathbf{a}-\mathbf{b} \mathrm{P} 1, \mathbf{c}-\mathbf{d} \mathrm{P} 2$, and $\mathbf{e}-\mathbf{f}$ the differences (P2-P1) during ASO. The left column displays the vertical p-velocity (shading; $10^{-2} \mathrm{~Pa} \mathrm{~s}^{-1}$ ) and specific humidity (contour; $\mathrm{g} \mathrm{kg}^{-1}$ ), while the right column shows the relative vorticity (shading; $10^{-5} \mathrm{~s}^{-1}$ ), horizontal divergence (con-

tour; $\left.10^{-5} \mathrm{~s}^{-1}\right)$, and vectors from meridional wind $\left(\mathrm{m} \mathrm{s}^{-1}\right)$ and vertical p-velocity $\left(10^{-2} \mathrm{~Pa} \mathrm{~s}^{-1}\right)$. The contour intervals are $0.1 \mathrm{~g} \mathrm{~kg}^{-1}$ in the left column and $5 \times 10^{-7} \mathrm{~s}^{-1}$ in the right column. The vertical p-velocity was multiplied by -1 . The scales of shading and vectors are displayed at the bottom of each panel

OLR anomalies along the equator (Fig. 6c). These differences imply that the enhanced Walker circulation induced descending anomalies over and around the maritime continent and eastern tropical Indian Ocean. The vertical wind shear was strengthened over the western tropical Indian Ocean and central tropical Pacific (Fig. 6b), which corresponded to the enhanced convection anomalies over the western Pacific. Positive SST anomalies and relatively weak negative OLR anomalies were located over the equatorial Indian Ocean (Fig. 6a, b). Because the convective activity with the BSISO was initiated from the equatorial

Indian Ocean (Kemball-Cook and Wang 2001; Wang et al. 2005), the positive SST anomalies can strengthen the convective activity associated with the BSISO through an enhanced moisture convergence in the lower troposphere (Sabeerali et al. 2014). Positive (negative) SST anomalies appeared in the western (central) tropical Pacific (Fig. 6b), which corresponded to the convection anomalies over the western and central Pacific, and resembled the negative pattern of the Interdecadal Pacific Oscillation (IPO). The IPO index often has a negative sign after 2000 (England et al. 2014). The differences in moisture at $1000 \mathrm{hPa}$ significantly 


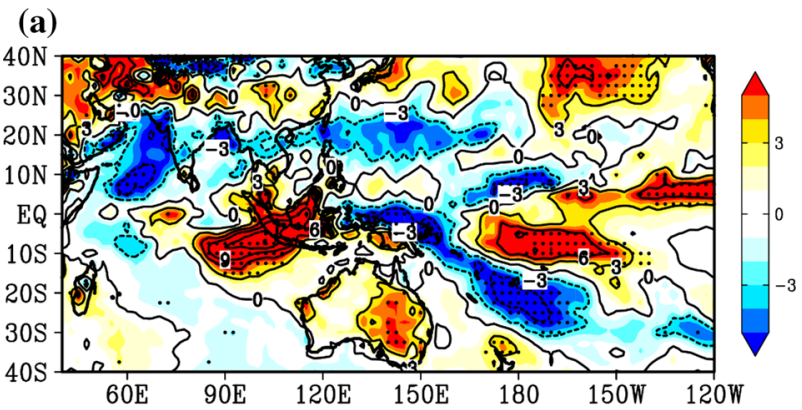

(b)

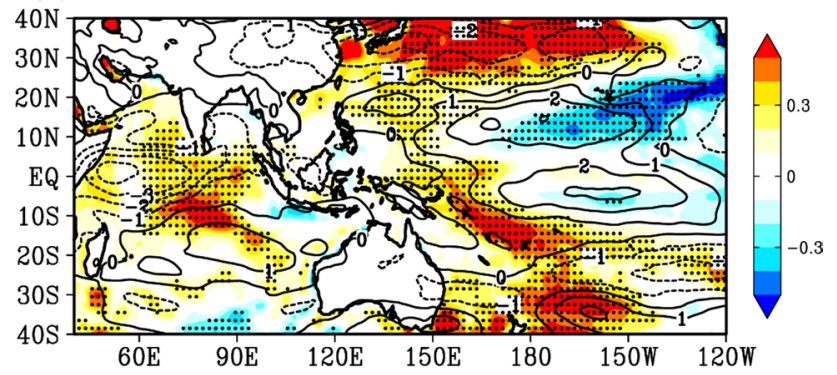

(c)

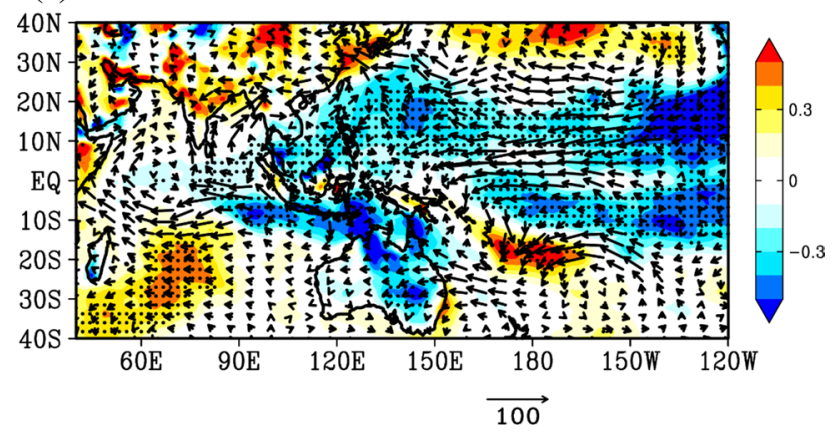

Fig. 6 a Differences (P2-P1) in the seasonal average in ASO for OLR (shading and contour; $\mathrm{W} \mathrm{m}^{-2}$ ), b SST (shading; $\mathrm{K}$ ) and vertical wind shear composed of zonal wind at $200 \mathrm{hPa}$ subtracted from that at $850 \mathrm{hPa}$ (contour; $\mathrm{m} \mathrm{s}^{-1}$ ), and $\mathbf{c}$ water vapor at $1000 \mathrm{hPa}$ (shading; $\mathrm{g} \mathrm{kg}^{-1}$ ) and vertically integrated (1000-300 hPa) water vapor flux (vector; $\mathrm{kg} \mathrm{m}^{-1} \mathrm{~s}^{-1}$ ). The dotted grid indicates that shading is significant at the $5 \%$ level. The scale of shading (vector) is on the right (bottom) of panel

decreased around the eastern tropical Indian Ocean and western tropical Pacific. This decreased moisture anomaly weakened the north-south gradient near the equator, reducing the phase speed of northward propagation associated with the BSISO activity (Jiang et al. 2004).

Figure 7 displays the vertical structure of the differences in zonal wind and vertical p-velocity near the equator between P1 and P2. In the equatorial Indian Ocean, the westerly (easterly) anomalies in the lower (upper) troposphere enhanced the vertical wind shear. The slowdown of the northward propagation of convection seems to be limited (Table 2), because the enhanced vertical wind shear can affect the phase speed far from the equator (Jiang et al.

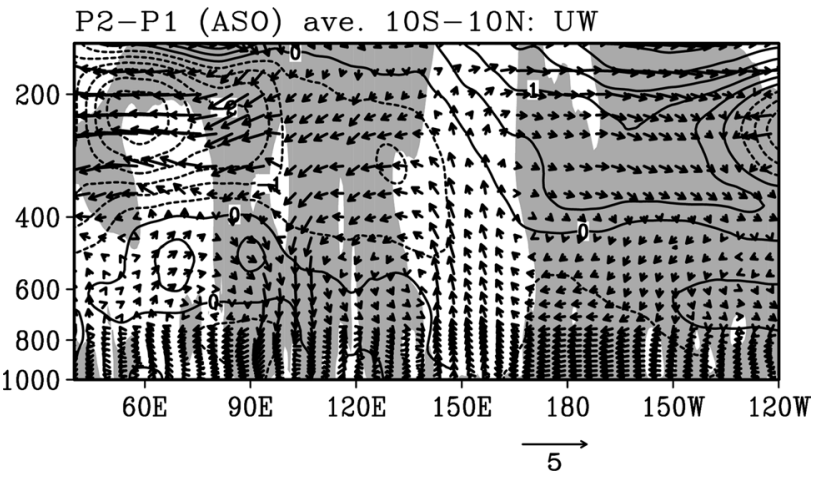

Fig. 7 Longitude-height cross-section averaged between $10^{\circ} \mathrm{S}$ and $10^{\circ} \mathrm{N}$ for the differences (P2-P1) of vectors from zonal wind $\left(\mathrm{m} \mathrm{s}^{-1}\right)$ and vertical p-velocity $\left(10^{-2} \mathrm{~Pa} \mathrm{~s}^{-1}\right)$. The contour interval is $0.5 \mathrm{~m} \mathrm{~s}^{-1}$. Shading indicates downward motion. The vertical $\mathrm{p}$-velocity was multiplied by -1 . The scales of the vectors are displayed at the bottom of panel

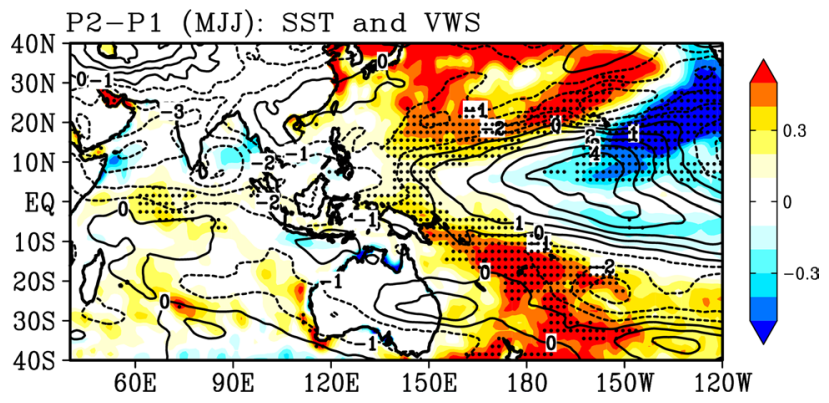

Fig. 8 Same as Fig. 6b, but averaged from May to July

2004). Ascending anomalies appeared at $150^{\circ} \mathrm{E}$ and compensatory descending anomalies were present on both sides of the ascending anomalies. This implies that the strengthened Walker circulation can suppress convective activity in the tropical Indian Ocean. In contrast, the positive SST anomalies in the tropical Indian Ocean increased the convective instability (Fig. 6b). Thermal convection tends to be suppressed by descending anomalies, whereas once a disturbance occurs with large-scale convergences, such as an arrival of the active BSISO signal, convection is enhanced using the convective instability. Therefore, the descending anomalies and positive SST anomalies can amplify the active and break cycle of BSISO in P2.

To determine why the enhanced BSISO activity was limited during ASO in P2 (Table 1), we displayed the epochal differences in SST and vertical wind shear during MJJ between P1 and P2 (Fig. 8). Positive (negative) SST anomalies were apparent in the western (central) tropical Pacific. A strengthened Walker circulation was apparent during MJJ and ASO (figure not shown), with SST anomalies over the Pacific. On the other hand, the positive SST anomalies were 
relatively small in the tropical Indian Ocean compared to the ASO condition. The relatively weak warming in the tropical Indian Ocean implies that active convection associated with the BSISO was small during MJJ. Thus, the seasonal dependency of the decadal variability may be caused by the limited tropical Indian Ocean warming in late summer.

\section{Abrupt weakening of the BSISO in 2009-2014}

BSISO activity rapidly weakened from P2 to P3 (Fig. 1; Table 1). Figure 9 shows the ratio of bandpass-filtered OLR to the total daily variance during JASO in P2 and P3. The

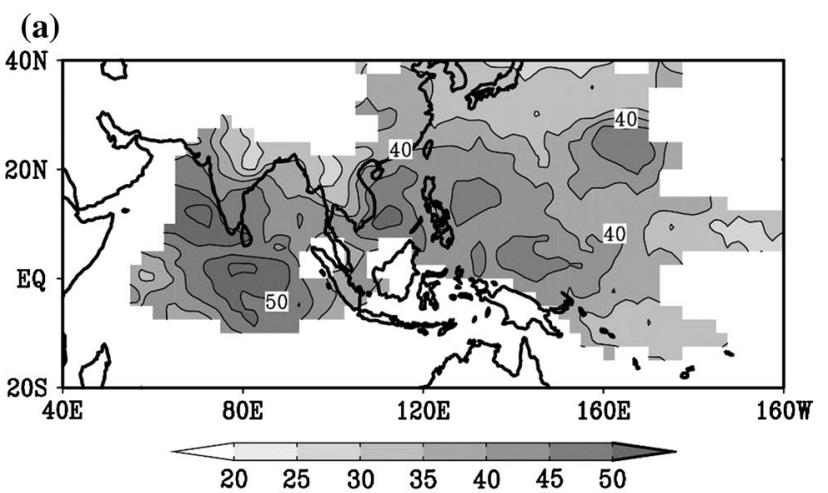

(b)

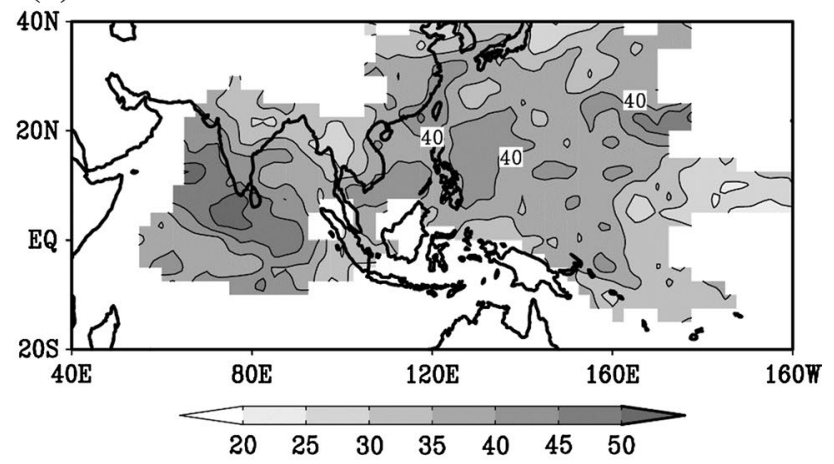

(c)

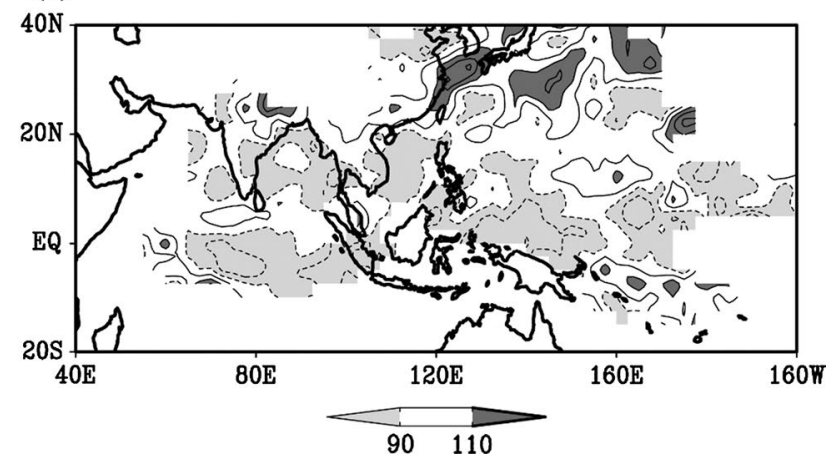

Fig. 9 Same as Fig. 3, but for P2 and P3 averaged from July to October
OLR pattern in JASO was almost the same as that in ASO (Figs. 3a, 9a). In P3, BSISO activity broadly decreased in the tropical Indian Ocean and the western tropical Pacific (Fig. 9b). The ratio of P3 to P2 also clearly indicated the weakened BSISO activity in P3 (Fig. 9c). In particular, BSISO activity weakened more over the southern tropical Indian Ocean than over the northern part.

To examine the decadal change in the temporal pattern of convective activity between $\mathrm{P} 2$ and $\mathrm{P} 3$, we produced a Hovmöller diagram of composite OLR and SST during JASO (Fig. 10). The northward propagation of the anomalies of convection and SST was clear during P2, whereas the amplitude of these anomalies was suppressed in P3. In particular, the center of the SST anomalies shifted slightly northward, which implied that the north-south asymmetric convection anomalies were excited. Concurrently, the southward propagation of convective activity from the equator was unclear. Furthermore in P3, this asymmetric structure was emphasized more in the

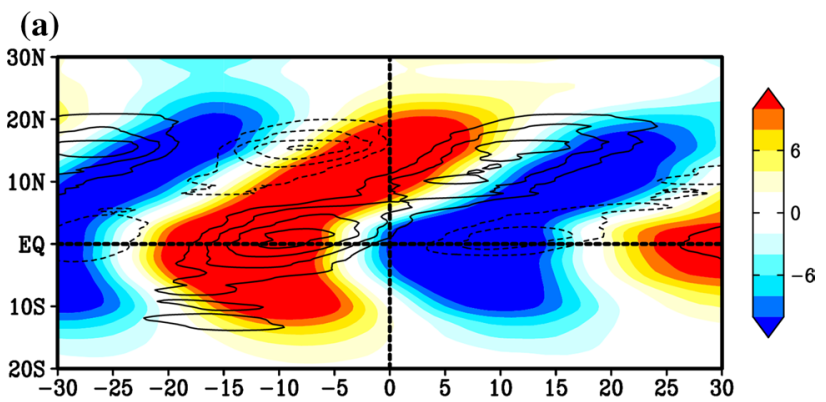

(b)

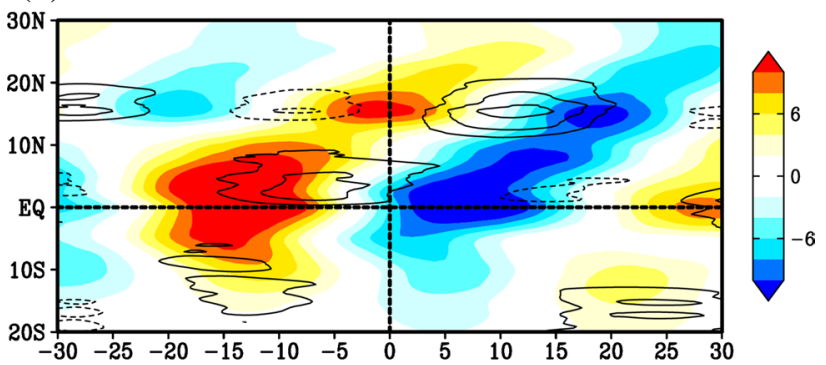

(c)

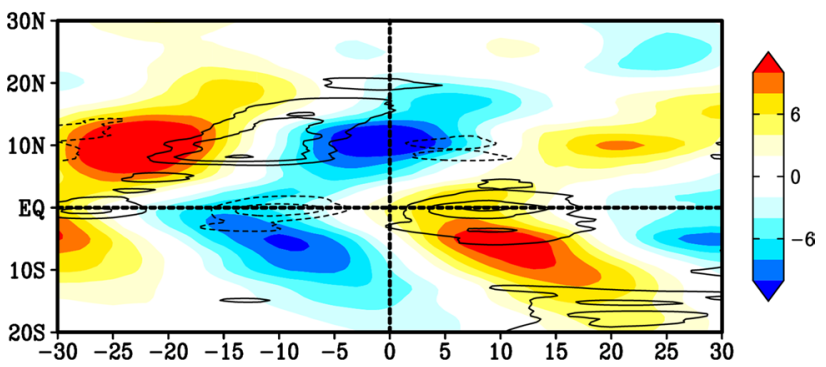

Fig. 10 Same as Fig. 4, but for P2 and P3 averaged from July to October 
active condition of BSISO events than in the break condition. The anomalies of convection and SST appeared in the South Indian Ocean around day -14 , whereas these anomalies were insignificant after day 0 . This suggests that convective activity related to the BSISO activity was suppressed over the southern tropical Indian Ocean in the active state of the BSISO. The phase speed of northward propagation of convective activity was accelerated in $\mathrm{P} 3$ (Table 2). In contrast, the eastward propagating speed of the BSISO was not significantly different between P2 and P3 (Table 2).

Figure 11 shows the average composite vertical structure of moisture and atmospheric circulation when the convection center appeared between the equator and $10^{\circ} \mathrm{N}(\mathrm{P} 2$ :

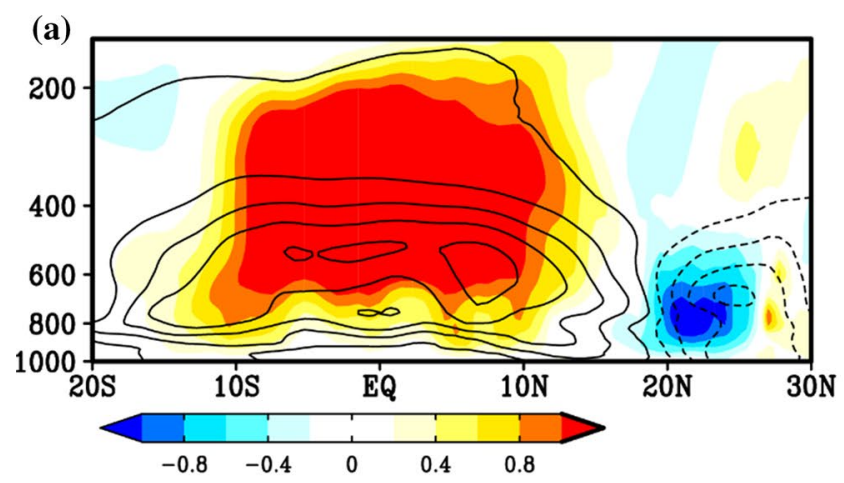

(c)

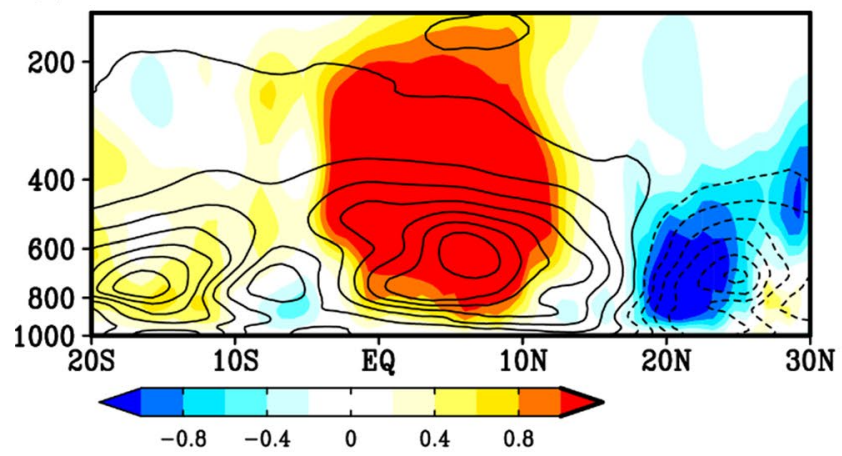

(e)

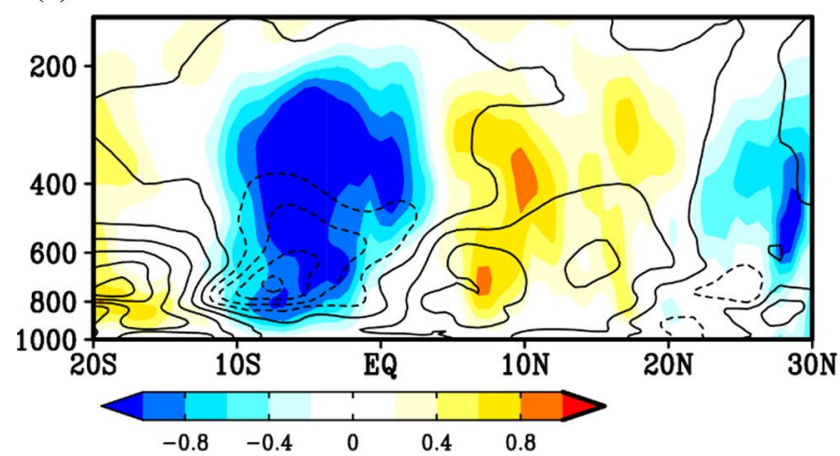

days 7-17, P3: days 7-13; Table 2). Compared with P2, the composite anomalies of ascending motion and moisture in the lower troposphere were slightly larger between the equator and $10^{\circ} \mathrm{N}$ during P3 (Fig. 11a, c). On the other hand, the ascending anomalies disappeared over the region south of the equator, indicating the northward concentrated vertical structure. Composite anomalies of atmospheric circulation over the southern tropical Indian Ocean were more significant than over the northern part. These characteristics were consistent with the spatial pattern of the weakened BSISO (Fig. 9c). The essential difference between P2 and P3 was the structural change of BSISO activity represented as the weakened activity over the southern tropical Indian Ocean.
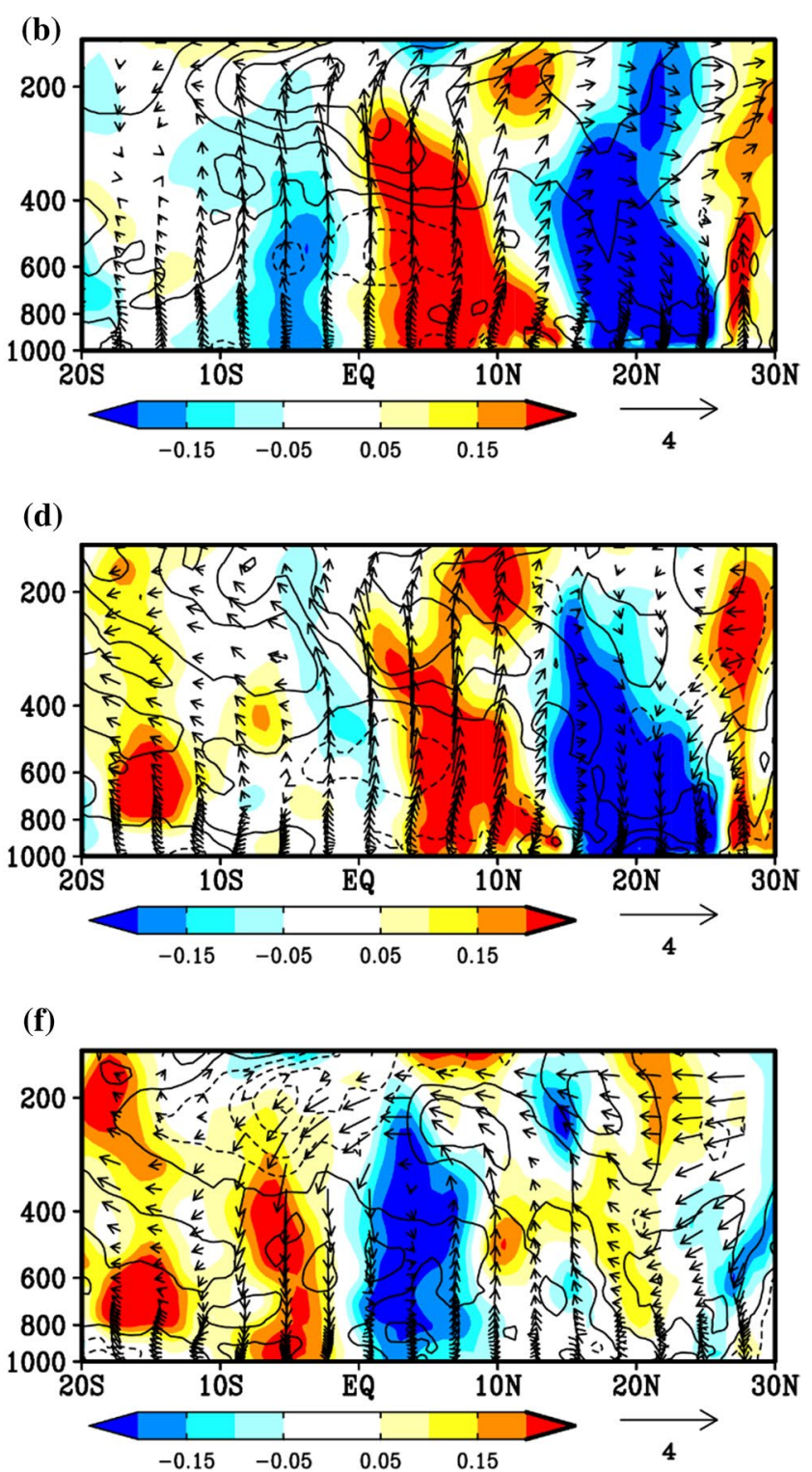

Fig. 11 Same as Fig. 5, but for P2 and P3 averaged from July to October 
To determine what causes the northward shifting shown in the composite anomalies, we investigated the epochal differences in OLR, SST, vertical wind shear composed of $200 \mathrm{hPa}$ zonal winds subtracted from $850 \mathrm{hPa}$, moisture at $1000 \mathrm{hPa}$, and the vertically (1000-300 hPa) integrated moisture flux during JASO between P2 and P3 (Fig. 12). Negative OLR anomalies appeared over the Arabian Sea and to the north and south of the equator around the maritime continent (Fig. 12a), while positive OLR anomalies were apparent over the South Indian Ocean and the central tropical Pacific. Compared with the differences between P1 and P2, OLR anomalies extended more northward in the western tropical Pacific. With regard to the convective anomalies, ascending (descending) anomalies were assumed to be east of the Indian subcontinent and around the maritime continent (from the equator to the South Indian Ocean), which implied that the local Hadley circulation was strengthened by the convection anomalies.

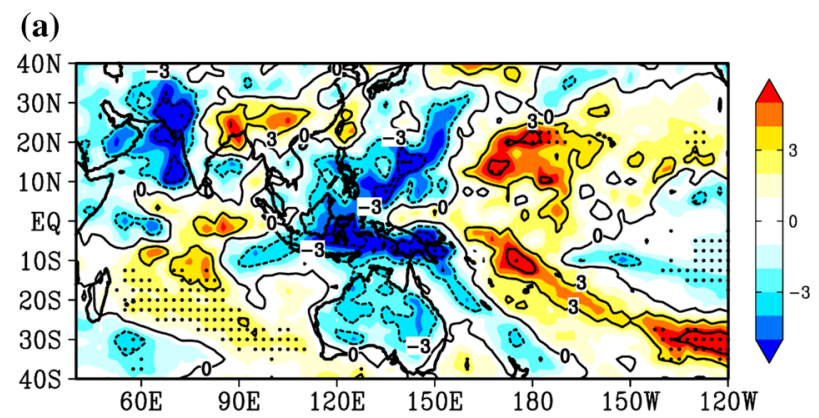

(b)

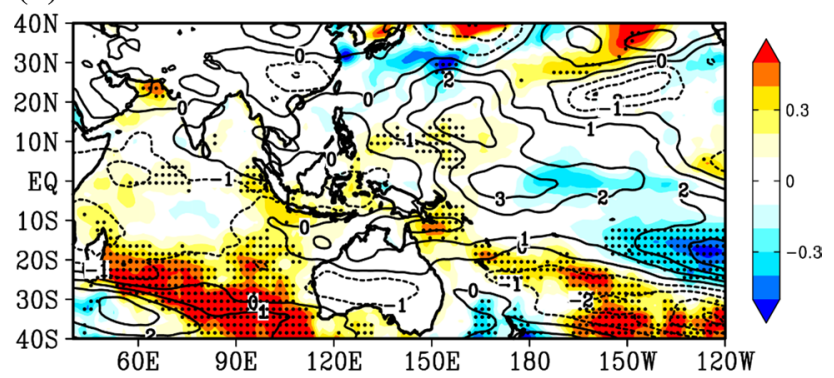

(c)

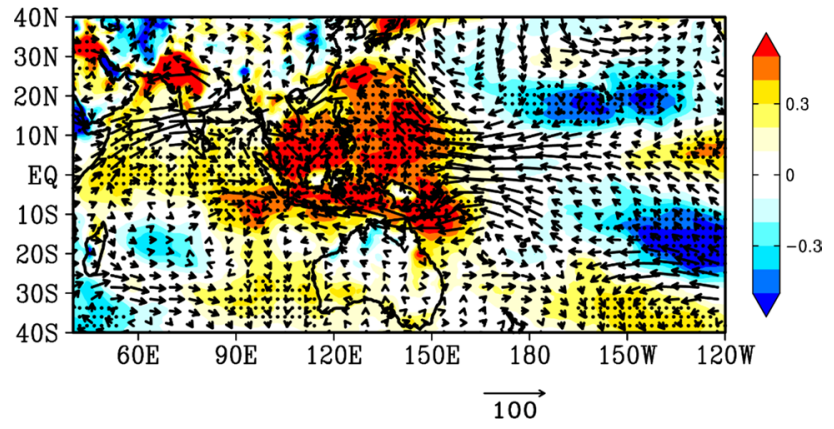

Fig. 12 Same as Fig. 6, but for P2 and P3 averaged from July to October

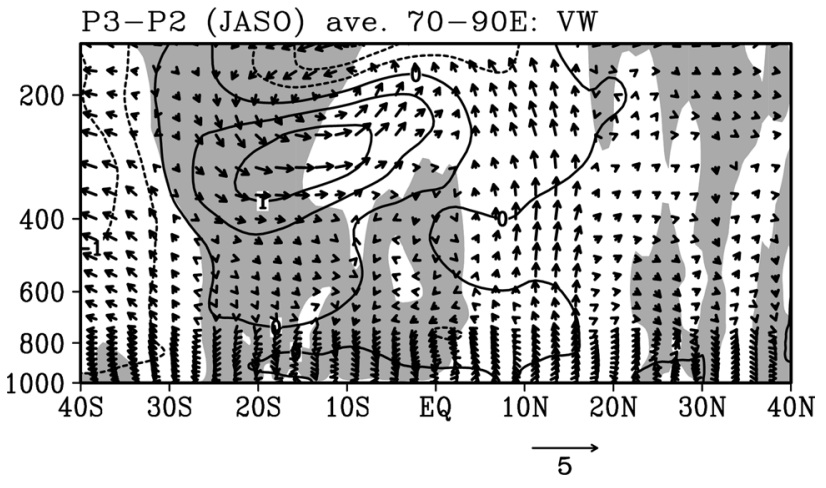

Fig. 13 Latitude-height cross-section averaged between $70^{\circ}$ and $90^{\circ} \mathrm{E}$ for the differences (P3-P2) of vectors from meridional wind $\left(\mathrm{m} \mathrm{s}^{-1}\right)$ and vertical p-velocity $\left(10^{-2} \mathrm{~Pa} \mathrm{~s}^{-1}\right)$. The contour interval is $0.5 \mathrm{~m} \mathrm{~s}^{-1}$. Shading indicates downward motion. The vertical p-velocity was multiplied by -1 . The scales of vectors are displayed at the bottom of panel

Suppressed BSISO activity during P3 may not be linked to the SST anomalies over the tropical Indian Ocean, because there was little change in SST over the region from P2 to P3 (Fig. 12b). Positive SST anomalies were apparent to the south of $20^{\circ} \mathrm{S}$ in the South Indian Ocean and around the maritime continent. The differences in moisture in the lower troposphere significantly increased in the tropical Indian Ocean and western tropical Pacific (Fig. 12c). The north-south gradient of these moisture anomalies strengthened near the equator, inducing acceleration of the phase speed of northward propagation related to the BSISO activity (Jiang et al. 2004).

Figure 13 displays the vertical structure of the differences in meridional wind and vertical p-velocity in the Indian Ocean from P2 to P3. Ascending anomalies appeared to the north of the equator and compensatory descending anomalies were apparent from the equator to the South Indian Ocean, which suggests an enhanced local Hadley circulation. The ascending anomalies were caused by the strengthened convective activity from the Arabian Sea to the maritime continent (Fig. 12a), which is rooted for the positive SST anomalies in the Indian Ocean and around the maritime continent (Fig. 12b). The enhanced local Hadley circulation can suppress convective activity over the southern tropical Indian Ocean. Thus, it is thought that the decadal change in BSISO activity between P2 and P3 was linked to the enhanced local Hadley circulation.

\section{Summary}

We investigated the decadal change in the spatiotemporal structure of the BSISO during 1979-2015. A two-decadal change was found around 1998 and 2009, and was more 
(a)

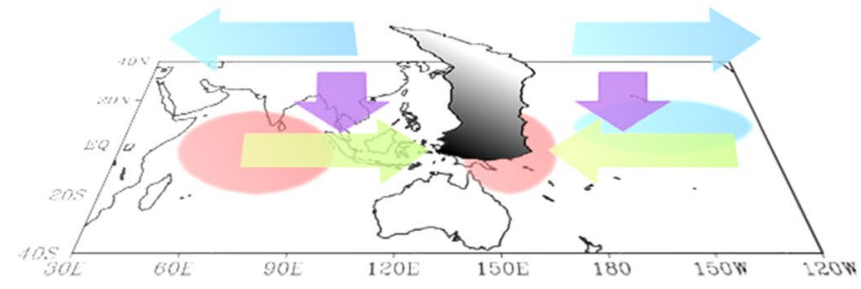

Fig. 14 Schematic illustration of the environmental changes affecting the decadal change in BSISO activity $\mathbf{a}$ from $\mathrm{P} 1$ to $\mathrm{P} 2$ and $\mathbf{b}$ from $\mathrm{P} 2$ to P3. The red (blue) shading indicates positive (negative) SST

prominent in late summer than in early summer. The decadal change was correlated with the difference in seasonal mean SST over the tropical Asian monsoon region during 1984-1998 (P1), 1999-2008 (P2), and 2009-2014 (P3). The variability of seasonal mean SST may be linked to the improvement of the decadal change in the BSISO activity.

Compared to P1, BSISO activity was significantly large from August to October in P2. Convection in the BSISO was strengthened in the tropical Indian Ocean and the South China Sea. The phase speed of the northward propagation of the convection was reduced. These decadal changes in BSISO activity were consistent with the results shown in Sabeerali et al. (2014). In contrast, the eastward propagating speed of the convection was not significantly different between P1 and P2. Under the background conditions in P2, positive SST anomalies over the western tropical Pacific can encourage active convection (Fig. 14a). The active convection reinforced the Walker circulation as ascending anomalies over the western tropical Pacific and compensated for the descending anomalies to the east and west sides of the enhanced convection. The strengthened Walker circulation suppressed convective activity in the tropical Indian Ocean. On the other hand, positive SST anomalies in the tropical Indian Ocean favored to the active convection in the BSISO. The background conditions of the SST and Walker circulation contributed to a clearer contrast between the active and break cycle of the BSISO, inducing the decadal change between P1 and P2.

In contrast to P2, BSISO activity was suppressed during $\mathrm{P} 3$. Convection in the BSISO tended to be inactive over the southern tropical Indian Ocean in P3, indicating northward shifted convection anomalies. The structural changes can be linked to the weakened BSISO activity. Additionally, the phase speed of the northward propagation of convection was accelerated, whereas the eastward propagating speed of the convection displayed less significant differences from $\mathrm{P} 2$ to $\mathrm{P} 3$. Under the background conditions in P3, positive SST anomalies around the maritime continent could strengthen convective activity (Fig. 14b). This enhanced convection intensified the local Hadley circulation between (b)

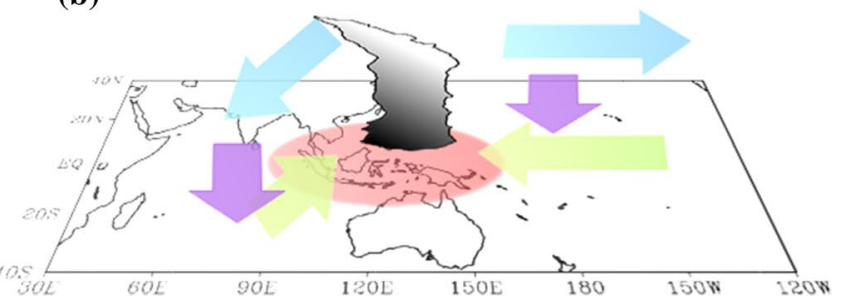

anomalies. The green (blue) vector depicts zonal wind anomalies in the lower (upper) troposphere. The purple vector indicates descending anomalies. The cloud icon indicates enhanced convection

the western tropical Pacific and the southern tropical Indian Ocean. Hence, the convection in the BSISO over the southern tropical Indian Ocean was suppressed.

This study confirmed the existence of the decadal variability in BSISO activity and discussed the background conditions required to control decadal variability. However, some questions still remain. For example, why is the significant difference in SST over the tropical Indian Ocean that affect the decadal change in BSISO activity limited in late summer between P1 and P2? To answer this question, a detailed investigation of the variability, including internal variability of the Indian Ocean, may be needed. It is also unclear how the background conditions quantitatively contribute to the decadal variability of BSISO activity. Because this study was limited in its analytical approach, sensitivity experiments are needed to verify the contribution of the background conditions to the decadal changes in the BSISO activity in more detail, using an atmospheric model that is able to realistically reproduce the BSISO activity.

Acknowledgments We thank Dr. Yoshida for fruitful discussions to the physical mechanism of BSISO and its decadal change. Two anonymous reviewers gave various constructive comments to further improve the original manuscript. This work was supported by JSPS KAKENHI Grant Number JP15K01177.

Open Access This article is distributed under the terms of the Creative Commons Attribution 4.0 International License (http://creativecommons.org/licenses/by/4.0/), which permits unrestricted use, distribution, and reproduction in any medium, provided you give appropriate credit to the original author(s) and the source, provide a link to the Creative Commons license, and indicate if changes were made.

\section{References}

AjayaMohan RS, Goswami BN (2003) Potential predictability of the Asian summer monsoon on monthly and seasonal time scales. Meteorol Atmos Phys 84:83-100

Charney JG, Shukla J (1981) Predictability of monsoons. Monsoon Dynamics, Cambridge University Press, pp 99-109 
Dee DP, Uppala SM, Simmons AJ, Berrisford P, Poli P, Kobayashi S, Andrae U, Balmaseda MA, Balsamo G, Bauer P, Bechtold P, Beljaars ACM, van de Berg L, Bidlot J, Bormann N, Delsol C, Dragani R, Fuentes M, Geer AJ, Haimberger L, Healy SB, Hersbach H, Hólm EV, Isaksen L, Kållberg P, Köhler M, Matricardi M, McNally AP, Monge-Sanz BM, Morcrette J-J, Park B-K, Peubey C, de Rosnay P, Tavolato C, Thépaut J-N, Vitart F (2011) The ERA-Interim reanalysis: configuration and performance of the data assimilation system. Q J R Meteorol Soc 137:553-597

Drbohlav H-KL, Wang B (2005) Mechanism of the northward-propagating intraseasonal oscillation: insights from a zonally symmetric model. J Clim 18:952-972

Duchon CE (1979) Lanczos filtering in one and two dimensions. J Appl Meteorol 18:1016-1022

England MH, McGregor S, Spence P, Meehl GA, Timmermann A, Cai W, Gupta AS, McPhaden MJ, Purich A, Santoso A (2014) Recent intensification of wind-driven circulation in the Pacific and the ongoing warming hiatus. Nat Clim Chang 4:222-227

Goswami BN, AjayaMohan RS (2001) Intraseasonal oscillations and interannual variability of the Indian summer monsoon. J Clim 14:1180-1198

Goswami BN, Xavier PK (2003) Potential predictability and extended range prediction of Indian summer monsoon breaks. Geophys Res Lett. doi:10.1029/2003GL017810

Hartmann DL, Michelsen ML (1989) Intraseasonal periodicities in Indian rainfall. J Atmos Sci 46:2838-2862

Jiang X, Li T, Wang B (2004) Structures and mechanisms of the northward propagating boreal summer intraseasonal oscillation. J Clim 17:1022-1039

Kajikawa Y, Wang B (2012) Interdecadal change of the South China Sea summer monsoon onset. J Clim 25:3207-3218

Kajikawa Y, Yasunari T (2005) Interannual variability of the 10-25and 30-60-day variation over the South China Sea during boreal summer. Geophys Res Lett. doi:10.1029/2004GL021836

Kajikawa Y, Yasunari T, Wang B (2009) Decadal change in intraseasonal variability over the South China Sea. Geophys Res Lett. doi:10.1029/2009GL037174

Kawamura R (1998) A possible mechanism of the Asian summer monsoon-ENSO coupling. J Meteorol Soc Jpn 76:1009-1027

Kemball-Cook S, Wang B (2001) Equatorial waves and air-sea interaction in the boreal summer intraseasonal oscillation. J Clim 14:2923-2942

Kikuchi K, Wang B, Kajikawa Y (2012) Bimodal representation of the tropical intraseasonal oscillation. Clim Dyn. doi:10.1007/ s00382-011-1159-1

Liebmann B, Smith CA (1996) Description of a complete (interpolated) outgoing longwave radiation dataset. Bull Am Meteorol Soc 77:1275-1277

Madden RA, Julian PR (1994) Observations of the 40-50-day tropical oscillation-a review. Mon Weather Rev 122:814-837

Murakami T (1972) Equatorial stratospheric waves induced by diabatic heat sources. J Atmos Sci 29:1129-1137

Murakami T, Matsumoto J (1994) Summer monsoon over the Asian continent and western North Pacific. J Meteorol Soc Jpn 72:719-745

Nitta T, Yamada S (1989) Recent warming of tropical sea surface temperature and its relationship to the Northern Hemisphere circulation. J Meteorol Soc Jpn 67:375-383
Ramamurthy K (1969) Monsoon of India: some aspects of the 'break' in the Indian southwest monsoon during July and August. Forecasting manual 1-57, No. IV 18.3. India Meterological Department, Poona, pp 1-57

Reynolds RW, Smith TM (1994) Improved global sea surface temperature analyses using optimum interpolation. J Clim 7:929-948

Sabeerali CT, Rao SA, George G, Rao DN, Mahapatra S, Kulkarni A, Murtugudde R (2014) Modulation of monsoon intraseasonal oscillations in the recent warming period. J Geophys Res Atmos 119:5185-5203. doi:10.1002/2013JD021261

Sperber KR, Slingo JM, Annamalai H (2000) Predictability and the relationship between subseasonal and interannual variability during the Asian summer monsoon. Q J R Meteorol Soc 126:2545-2574

Stephens GL, Webster PJ, Johnson RH, Engelen R, L'Ecuyer T (2004) Observational evidence for the mutual regulation of the tropical hydrological cycle and tropical sea surface temperatures. J Clim 17:2213-2224

Tomita T, Sato H, Nonaka M, Hara M (2007) Interdecadal variability of the early summer surface heat flux in the Kuroshio region and its impact on the Baiu frontal activity. Geophys Res Lett. doi:10. 1029/2007GL029676

Tomita T, Yamaura T, Kuwazuru Y (2013) Decadal-scale modulation of atmospheric circulation change at the onset of the western North Pacific summer monsoon. SOLA 9:161-165

Trenberth KE, Hurrell JW (1994) Decadal atmosphere-ocean variations in the Pacific. Clim Dyn 9:303-319

Wang B, LinHo (2002) Rainy season of the Asian-Pacific summer monsoon. J Clim 15:386-398

Wang B, Xie X (1997) A model for the boreal summer intraseasonal oscillation. J Atmos Sci 54:72-86

Wang B, Wu R, Lau K-M (2001) Interannual variability of the Asian summer monsoon: contrasts between the Indian and the western North Pacific-East Asian monsoons. J Clim 14:4073-4090

Wang B, Webster PJ, Teng H (2005) Antecedents and self-induction of active-break south Asian monsoon unraveled by satellites. Geophys Res Lett. doi:10.1029/2004GL020996

Watanabe M, Nitta T (1999) Decadal changes in the atmospheric circulation and associated surface climate variations in the Northern Hemisphere winter. J Clim 12:494-510

Webster PJ, Hoyos C (2004) Prediction of monsoon rainfall and river discharge on 15-30-day time scales. Bull Am Meteorol Soc 85:1745-1765

Wheeler MC, Hendon HH (2004) An all-season real-time multivariate MJO index: development of an index for monitoring and prediction. Mon Weather Rev 132:1917-1932

Yamaura T, Tomita T (2014) Two physical mechanisms controlling the interannual variability of Baiu precipitation. J Meteorol Soc Jpn 92:305-325

Yasunari T (1981) Structure of an Indian summer monsoon system with around 40-day period. J Meteorol Soc Jpn 59:336-354

Zhou T, Gong D, Li J, Li B (2009) Detecting and understanding the multi-decadal variability of the East Asian Summer Monsoonrecent progress and state of affairs. Meteorol Z 18:455-467 